\title{
Whole body protein anabolism in COPD patients and healthy older adults is not enhanced by adding either carbohydrates or leucine to a serving of protein
}

Citation for published version (APA):

Jonker, R., Deutz, N. E. P., Schols, A. M. W. J., Veley, E. A., Harrykissoon, R., Zachria, A. J., \& Engelen, M. P. K. J. (2019). Whole body protein anabolism in COPD patients and healthy older adults is not enhanced by adding either carbohydrates or leucine to a serving of protein. Clinical Nutrition, 38(4), 16841691. https://doi.org/10.1016/j.clnu.2018.08.006

Document status and date:

Published: 01/08/2019

DOI:

10.1016/j.clnu.2018.08.006

Document Version:

Publisher's PDF, also known as Version of record

\section{Document license:}

Taverne

Please check the document version of this publication:

- A submitted manuscript is the version of the article upon submission and before peer-review. There can be important differences between the submitted version and the official published version of record.

People interested in the research are advised to contact the author for the final version of the publication, or visit the DOI to the publisher's website.

- The final author version and the galley proof are versions of the publication after peer review.

- The final published version features the final layout of the paper including the volume, issue and page numbers.

Link to publication

\footnotetext{
General rights rights.

- You may freely distribute the URL identifying the publication in the public portal. please follow below link for the End User Agreement:

www.umlib.nl/taverne-license

Take down policy

If you believe that this document breaches copyright please contact us at:

repository@maastrichtuniversity.nl

providing details and we will investigate your claim.
}

Copyright and moral rights for the publications made accessible in the public portal are retained by the authors and/or other copyright owners and it is a condition of accessing publications that users recognise and abide by the legal requirements associated with these

- Users may download and print one copy of any publication from the public portal for the purpose of private study or research.

- You may not further distribute the material or use it for any profit-making activity or commercial gain

If the publication is distributed under the terms of Article $25 \mathrm{fa}$ of the Dutch Copyright Act, indicated by the "Taverne" license above, 
Original article

\title{
Whole body protein anabolism in COPD patients and healthy older adults is not enhanced by adding either carbohydrates or leucine to a serving of protein
}

\author{
Renate Jonker ${ }^{a}$, Nicolaas E.P. Deutz ${ }^{a}$, Annemie M.W.J. Schols ${ }^{b}$, Eugene A. Veley ${ }^{c}$, \\ Rajesh Harrykissoon ${ }^{\mathrm{d}}$, Anthony J. Zachria ${ }^{\mathrm{d}}$, Mariëlle P.K.J. Engelen ${ }^{\mathrm{a},{ }^{*}}$ \\ ${ }^{a}$ Center for Translational Research in Aging \& Longevity, Dept. of Health and Kinesiology, Texas A\&M University, College Station, TX, USA \\ ${ }^{\mathrm{b}}$ NUTRIM School for Nutrition, Toxicology and Metabolism, Dept. of Respiratory Medicine, Maastricht University Medical Centre, Maastricht, The \\ Netherlands \\ ${ }^{\mathrm{c}}$ Dept. of Medicine, Div. of Pulmonary \& Critical Care Medicine, Baylor Scott \& White Medical Center, College Station, TX, USA \\ ${ }^{\mathrm{d}}$ Center for Pulmonary and Sleep Disorders, College Station Medical Center, College Station, TX, USA
}

\section{A R T I C L E I N F O}

\section{Article history:}

Received 14 November 2017

Accepted 4 August 2018

\section{Keywords:}

COPD

Leucine

Carbohydrate

Coingestion

Anabolic response

\begin{abstract}
S U M M A R Y
Background \& aims: Carbohydrates (CHO) and leucine (LEU) both have insulinotropic properties, and could therefore enhance the protein anabolic capacity of dietary proteins, which are important nutrients in preventing muscle loss in patients with Chronic Obstructive Pulmonary Disease (COPD). LEU is also known to activate protein anabolic signaling pathways independent of insulin. Based on our previous findings in COPD, we hypothesized that whole body protein anabolism is enhanced to a comparable extent by the separate and combined co-ingestion of CHO and LEU with protein.

Methods: To disentangle the protein anabolic effects of $\mathrm{CHO}$ and/or free LEU when co-ingested with a high-quality protein, we studied 10 patients with moderate to very severe COPD and dyspnea (GOLD: IIIV, mMRC dyspnea scale $\geq 2$ ), at risk for muscle loss, and 10 healthy age- and gender-matched controls. On four occasions, in a single-blind randomized crossover design, each subject ingested a drink containing $0.6 \mathrm{~g} / \mathrm{kg}$ fat-free mass (ffm) hydrolyzed casein protein with, a) no add-ons (protein), b) $0.3 \mathrm{~g} / \mathrm{kg}$ $\mathrm{ffm}$ CHO (protein + CHO), c) $0.095 \mathrm{~g} / \mathrm{kg}$ ffm leucine (protein + LEU), d) both add-ons (protein $+\mathrm{CHO}+\mathrm{LEU})$. Whole body protein breakdown (PB), protein synthesis (PS), and net protein balance $(=\mathrm{PS}-\mathrm{PB})$ were measured by IV primed and continuous infusion of L-[ring- $\left.{ }^{2} \mathrm{H}_{5}\right]$-phenylalanine and $\mathrm{L}-\left[{ }^{13} \mathrm{C}_{9},{ }^{15} \mathrm{~N}\right]$-tyrosine. $\mathrm{L}-\left[{ }^{15} \mathrm{~N}\right]$-phenylalanine was added to the protein drinks to measure splanchnic extraction.

Results: In both groups, whole body PS, PB and net protein balance responses were comparable between the four protein drinks, despite higher postprandial plasma LEU concentrations for the LEU supplemented drinks $(P<0.05)$, and higher insulin concentrations for the $\mathrm{CHO}$ supplemented drinks as compared to the protein only drink $(P<0.05)$.

Conclusions: Adding $\mathrm{CHO}$ and/or LEU to a serving of high-quality protein does not further augment whole body protein anabolism in dyspneic COPD patients at risk for muscle loss or healthy older adults. Trial registry: ClinicalTrials.gov; No. NCT01734473; URL: www.clinicaltrials.gov.
\end{abstract}

๑) 2018 Elsevier Ltd and European Society for Clinical Nutrition and Metabolism. All rights reserved.
Abbreviations: CHO, carbohydrates; COPD, chronic obstructive pulmonary disease; cTTR, corrected tracer-tracee ratio; FFM, fat-free mass; FSR, fractional synthesis rate; HOMA index for IR, homeostasis model assessment of insulin resistance; LEU, leucine; PB, protein breakdown; PHE, phenylalanine; PS, protein synthesis; Ra, rate of appearance; TTR, tracer to tracee ratio; TYR, tyrosine.

* Corresponding author. Center for Translational Research in Aging \& Longevity, Dept. of Health and Kinesiology, Texas A\&M University, 675 John Kimbrough Blvd, College Station, TX, USA. Fax: +1979 8623244.

E-mail address: mpkj.engelen@ctral.org (M.P.K.J. Engelen).

\section{Introduction}

Nutritional interventions with high anabolic effectiveness are clinically important in patients with Chronic Obstructive Pulmonary Disease (COPD) with moderate to severe dyspnea at risk for muscle loss as disturbances in intermediary amino acid and protein metabolism are already present in these normal weight patients [1-3]. Although high-quality proteins [4], and specifically dietary 
essential amino acids [5] are very effective in the acute stimulation of protein anabolism in COPD patients, the specific contribution of leucine (LEU) remains controversial.

LEU is of particular interest as it is unique among the essential amino acids for its potential to activate signaling pathways that stimulate muscle protein synthesis (PS) [6,7]. LEU acts on these pathways through insulin dependent as well as independent mechanisms [6,7]. In humans, insulin administration has been suggested to improve net protein balance by inhibiting muscle protein breakdown (PB) $[8,9]$. LEU and CHO therefore partially work through the same mechanism to promote increases in protein anabolism, namely by stimulation of insulin. In contrast, we observed no anabolic effects of LEU ingestion with a bolus of highquality protein or dietary essential amino acids in COPD patients $[4,5]$. However in these COPD studies, carbohydrates (CHO) were always added to the protein/amino acid meal. It is particularly important for COPD patients to disentangle the anabolic effects of LEU and CHO, as this patient group is characterized by alterations in LEU metabolism $[5,10,11]$ and glucose intolerance $[12,13]$. Furthermore, minimizing supplement dose by optimizing the quality is clinically important particularly in dyspneic COPD patients at risk for muscle loss as it may impair their food intake.

Based on our previous findings in COPD, we hypothesized in the present study that whole body protein anabolism is enhanced to a comparable extent by the separate and combined co-ingestion of $\mathrm{CHO}$ and LEU with protein. Furthermore, we tested whether the observations are COPD specific or also present in healthy control subjects. To examine this, we studied the response effect of administering a serving of high-quality protein with or without the addition of free LEU and/or CHO on whole body protein metabolism and glucose and insulin kinetics in COPD patients with moderate to severe dyspnea at risk for muscle loss as compared to healthy older adults, using stable isotope tracer methodology.

\section{Subjects and methods}

\subsection{Subjects}

The study population consisted of 10 older adults with a clinical diagnosis of moderate to very severe airflow obstruction (grades IIIV), according to the established Global Initiative for Chronic Obstructive Lung Disease (GOLD) guidelines [14], moderate to severe dyspnea (mMRC dyspnea scale $\geq 2$ ), and 11 healthy participants of similar age and gender. We recruited participants through pulmonologist referral and local advertising. We assessed medical history and medication use as part of the screening process. COPD patients were in clinically stable condition and not suffering from a respiratory tract infection or exacerbation of their disease $\leq 4$ weeks before the study. As maintenance therapy, 9 patients received bronchodilator treatment, 8 patients received inhalation corticosteroids, and 7 patients were on long-term oxygen therapy. Eight patients compared to 4 controls were treated for hypertension, 5 patients compared to 2 controls were treated for depression and/or anxiety, and 2 patients versus 2 controls received medication for dyslipidemia. The use of systemic corticosteroids $\leq 1$ month before the study was an exclusion criteria, as well as malignancy, recent myocardial infarction, recent surgery and severe endocrine, hepatic or renal disorders. We obtained written informed consent from all participants, and the Texas A\&M University Institutional Review Board approved the study (no. 2012-0561).

\subsection{Lung function and anthropometric data}

We measured forced expiratory volume in $1 \mathrm{~s}\left(\mathrm{FEV}_{1}\right)$ and forced vital capacity in all participants, with the highest value from $\geq 3$ technically acceptable maneuvers being used. Spirometric reference values were those of a US population [15]. We measured height and weight using a stadiometer and beam scale, respectively. We assessed body composition, including whole body fatfree mass (FFM), by dual-energy X-ray absorptiometry (Hologic QDR 4500).

\subsection{Study design}

We studied all participants on four experimental test days $(\geq 1$ day apart and $\leq 2$ days per week) within a time period of 1 month (Fig. 1). Test days started in the early morning after an overnight fast, and lasted $5.5 \mathrm{~h}$, during which participants were in a supine position. After insertion of a catheter into an antecubital vein, the first blood sample was taken to measure natural background isotope enrichment. Consecutively, we started a primed, constant intravenous infusion of $\mathrm{L}$-[ ring- $\left.{ }^{2} \mathrm{H}_{5}\right]$-phenylalanine $\left(\left[{ }^{2} \mathrm{H}_{5}\right]-\mathrm{PHE}\right.$ : prime $=270 \mu \mathrm{mol}$; infusion $\left.=270 \mu \mathrm{mol} \times \mathrm{h}^{-1}\right)$ and L-[U- $\left.-{ }^{13} \mathrm{C}_{9},{ }^{15} \mathrm{~N}\right]-$ tyrosine $\left(\left[\mathrm{U}-{ }^{13} \mathrm{C}_{9},{ }^{15} \mathrm{~N}\right]\right.$-TYR: prime $=8.5 \mu \mathrm{mol}$; infusion $=8.5 \mu \mathrm{mol}$ $\left.\times \mathrm{h}^{-1}\right)$ to assess whole body protein metabolism. At the same time, we gave an oral bolus dose of $\mathrm{L}-\left[\right.$ ring- $\left.{ }^{2} \mathrm{H}_{4}\right]$-tyrosine to prime the plasma pool $\left(\left[{ }^{2} \mathrm{H}_{4}\right]\right.$-TYR: prime $\left.=25.5 \mu \mathrm{mol}\right)$. We also placed a second catheter for arterialized venous blood sampling in a superficial dorsal vein of the contralateral hand or lower arm. The hand was placed in a thermostatically controlled heated box, a technique to mimic direct arterial sampling [16]. We obtained arterialized-venous blood samples at 70, 80, and 90 min after the start of infusion for the measurement of isotope enrichment values and plasma concentrations of amino acids, glucose and insulin in the postabsorptive state, and at 15, 30, 45, 60, 90, 120, 150, 180, 210

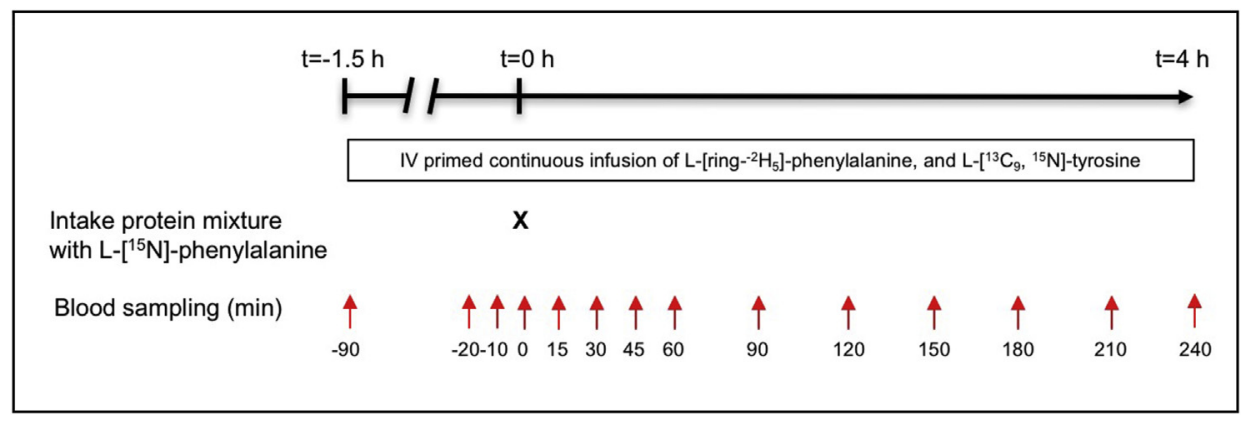

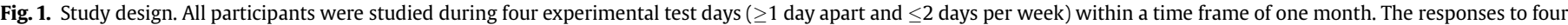

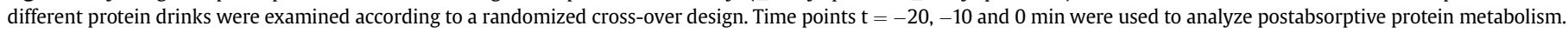
Postprandial protein kinetics were measured by using the time points $\mathrm{t}=0-240 \mathrm{~min}$ in order to calculate the area under the curve between 0 and 4 h. 
and 240 min after intake of the protein drinks for similar postprandial assessments.

\subsection{Protein drinks}

Participants received one out of four protein drinks each test day, according to a single-blind randomized cross-over design. Protein drinks were ingested orally and consisted of $0.6 \mathrm{~g} / \mathrm{kg} \mathrm{ffm}$ hydrolyzed casein protein (PeptoPro ${ }^{\circledR}$ hydrolyzed caseinate, True Nutrition (Vista, CA, USA) with, a) no add-ons (protein), b) $0.3 \mathrm{~g} / \mathrm{kg}$ ffm CHO (protein + CHO), c) $0.095 \mathrm{~g} / \mathrm{kg} \mathrm{ffm} \mathrm{leucine} \mathrm{(protein} \mathrm{+} \mathrm{LEU),}$ d) both add-ons (protein $+\mathrm{CHO}+\mathrm{LEU}$ ). $\mathrm{CHO}$ were given in the form of maltodextrin. We dissolved all components in non-caloric soda $(6 \mathrm{~mL} / \mathrm{kg} \mathrm{ffm})$, and added $5.45 \mathrm{mg} / \mathrm{kg}$ ffm L- $\left[{ }^{15} \mathrm{~N}\right]$-phenylalanine $\left(\left[{ }^{15} \mathrm{~N}\right]\right.$-PHE) (i.e. $10 \%$ of PHE content) to each of the drinks for the measurement of splanchnic PHE extraction. For an average person of $50 \mathrm{~kg}$ FFM, this would mean that the bolus meal contained $30 \mathrm{~g}$ hydrolyzed caseinate with/without $15 \mathrm{~g} \mathrm{CHO}$ and the addition of free LEU increased the total LEU content from 20 to $40 \%$ (from $\sim 3$ to $7.7 \mathrm{~g}$ ) of the essential amino acid content.

\subsection{Sample processing and biochemical analysis}

We collected arterialized-venous blood samples in tubes with lithium heparin or EDTA (Sarstedt, Nümbrecht, Germany), and immediately put them on ice to minimize enzymatic reactions. We centrifuged the blood $\left(5 \mathrm{~min}, 8000 \mathrm{~g}, 4^{\circ} \mathrm{C}\right.$ ) and put a portion of the plasma in 50\% trichloroacetic acid matrices for deproteinization. We instantly froze the plasma and stored it at $-80{ }^{\circ} \mathrm{C}$ until further analyses.

Samples were analyzed in batch. We determined isotope tracer enrichments and concentrations on a liquid chromatographyelectrospray ionization-tandem mass spectrometry (LC/MS-MS) system (QTrap 5500 MS (AB Sciex, Foster City, CA) with ExpressHTUltra LC (Eksigent Div., AB Sciex, Foster City, CA) [4]. Enrichment was expressed as tracer (labeled substance)/tracee (unlabeled substance) ratio (TTR), and corrected for natural background abundance (cTTR). We determined plasma glucose concentrations using a COBAS c111 semiautomatic analyzer (Gluc2 Kit; Roche Diagnostics $($ ) $)$, and plasma insulin concentrations by enzyme linked immunosorbent assay (Alpco $\left.{ }^{\circledR}\right)$.

\subsection{Calculations}

For the assessment of plasma amino acid, glucose and insulin concentrations, we calculated the 4-h postprandial area under the curve (AUC) per individual, using the postabsorptive concentration as baseline reference. The AUC was then divided by time to obtain the average increase in postprandial plasma concentration.

We calculated whole body PHE and TYR appearance rates from the isotope enrichment values of $\left[{ }^{2} \mathrm{H}_{5}\right]$-PHE and $\left[{ }^{13} \mathrm{C}_{9},{ }^{15} \mathrm{~N}\right]$-TYR. In the postabsorptive state, enrichments were at isotopic steady state, and we calculated whole body PS, PB and net protein balance (PS - PB) using the standard steady state isotope dilution equations [4]. As we provided a bolus meal, the enrichments were not in steady state during the $4 \mathrm{~h}$ feeding period. The tracers were infused by primed continuous infusion and the response to the bolus meal was assessed by calculating the area under the curve between 0 and $4 \mathrm{~h}$, taking into consideration that the uptake of food is not complete after $4 \mathrm{~h}$ [17]. During the 4 -h postprandial state, we calculated whole body PS, PB, net protein balance and splanchnic PHE extraction using previously published steady state equations [18], adapted for the current non-steady state conditions [17]:
$\operatorname{RaPHE}\left[\right.$ ring $\left.-{ }^{2} \mathrm{H}_{5}\right]=\frac{F\left(\operatorname{PHE}\left[\text { ring }-{ }^{2} \mathrm{H}_{5}\right]\right)}{A V G \operatorname{cTTR}\left(\operatorname{PHE}\left[\text { ring }-{ }^{2} \mathrm{H}_{5}\right]\right)}$

$\operatorname{RaTYR}\left[{ }^{13} C_{9},{ }^{15} N\right]=\frac{F\left(\operatorname{TYR}\left[{ }^{13} C_{9},{ }^{15} N\right]\right)}{\operatorname{AVG} \operatorname{cTTR}\left(\operatorname{TYR}\left[{ }^{13} C_{9},{ }^{15} N\right]\right)}$

where RaPHE [ring- ${ }^{2} \mathrm{H}_{5}$ ] and RaTYR $\left[{ }^{13} \mathrm{C}_{9},{ }^{15} \mathrm{~N}\right](\mu \mathrm{mol} \times \mathrm{kg}$ $\mathrm{ffm}^{-1} \times \mathrm{h}^{-1}$ ) represent the average total systemic Ra of PHE and TYR calculated from the intravenous infusion of PHE [ring- $\left.{ }^{2} \mathrm{H}_{5}\right]$ and TYR $\left[{ }^{13} \mathrm{C}_{9},{ }^{15} \mathrm{~N}\right]$, respectively. $F$ represents the infusion rate $\left(\mu \mathrm{mol} \times \mathrm{kg} \mathrm{ffm}^{-1} \times \mathrm{h}^{-1}\right)$ of PHE $\left[\right.$ ring $\left.{ }^{2} \mathrm{H}_{5}\right]$ and TYR $\left[{ }^{13} \mathrm{C}_{9},{ }^{15} \mathrm{~N}\right]$. AVG (=average) of cTTR (PHE [ring- ${ }^{2} \mathrm{H}_{5}$ ]) is calculated as the AUC of cTTR (PHE [ring- $\left.{ }^{2} \mathrm{H}_{5}\right]$ ) divided by 240 (time in min). AVG CTTR (TYR $\left[{ }^{13} \mathrm{C}_{9},{ }^{15} \mathrm{~N}\right]$ ) is the AUC of cTTR (TYR $\left[{ }^{13} \mathrm{C}_{9},{ }^{15} \mathrm{~N}\right]$ ) divided by 240 (time in $\min$ ).

$$
\operatorname{RaPHE}\left[{ }^{15} N\right]=\frac{\text { tracer in } \operatorname{drink}\left(\operatorname{PHE}\left[{ }^{15} N\right]\right)}{A U C \operatorname{cTTR}\left(\operatorname{PHE}\left[{ }^{15} N\right]\right)}
$$

where Ra PHE $\left[{ }^{15} \mathrm{~N}\right]$ was recalculated per hour $(\mu \mathrm{mol} \times \mathrm{kg}$ $\mathrm{ffm}^{-1} \times \mathrm{h}^{-1}$ ) and represents the average total systemic Ra of PHE calculated from the oral intake of PHE $\left[{ }^{15} \mathrm{~N}\right]$.

$S P E-P H E=1-\frac{R a P H E\left[\text { ring }-{ }^{2} H_{5}\right]}{\operatorname{RaPHE}\left[{ }^{15} N\right]}$

Exogenous RaPHE $=$ Total PHE intake $\times \frac{\operatorname{RaPHE}\left[\operatorname{ring}-{ }^{2} H_{5}\right]}{\operatorname{RaPHE}\left[{ }^{15} \mathrm{~N}\right]}$

$P B=R a P H E\left[\right.$ ring $\left.-{ }^{2} H_{5}\right]-$ exogenous RaPHE

where SPE-PHE is the splanchnic extraction of PHE and exogenous Ra PHE $\left(\mu \mathrm{mol} \times \mathrm{kg} \mathrm{ffm}^{-1} \times \mathrm{h}^{-1}\right)$ represents the average systemic appearance of PHE from the drink, and PB is equal to endogenous RaPHE $\left(\mu \mathrm{mol} \times \mathrm{kg} \mathrm{ffm}^{-1} \times \mathrm{h}^{-1}\right)$. Total PHE intake is the intake of unlabeled PHE and labeled PHE $\left[{ }^{15} \mathrm{~N}\right]$ with the drink.

$$
\begin{aligned}
\text { Hydroxylation PHE }= & \text { RaTYR }\left[{ }^{13} C_{9},{ }^{15} N\right] \\
& \times \frac{A V G c T T R-T Y R\left[\text { ring }-{ }^{2} H_{4}\right]}{A V G c T T R-P H E\left[\text { ring }-{ }^{2} H_{5}\right]}
\end{aligned}
$$

$P S=R a P H E\left[{ }^{2} H_{5}\right]-$ hydroxylation PHE

Net protein balance $=P S-P B$

where hydroxylation of PHE $\left(\mu \mathrm{mol} \times \mathrm{kg} \mathrm{ffm}^{-1} \times \mathrm{h}^{-1}\right)$ represents the conversion PHE into TYR by the enzyme PHE hydroxylase. AVG cTTR-TYR $\left[{ }^{2} \mathrm{H}_{4}\right]$ is AUC of cTTR-TYR $\left[{ }^{2} \mathrm{H}_{4}\right]$ divided by 240 (time in min). AVG cTTR-PHE $\left[{ }^{2} \mathrm{H}_{5}\right]$ is AUC of CTTR-PHE $\left[{ }^{2} \mathrm{H}_{5}\right]$ divided by 240 (time in min). Net protein gain is present when net protein balance $>0$ and net protein loss when net protein balance $<0$.

\subsection{Statistical analysis}

Results are expressed as means \pm standard errors (SEs). We compared clinical characteristics of the study populations using either the unpaired Student's t-test or Fisher's exact test, depending on the variable. Whole body insulin resistance was assessed using the computerized homeostasis model assessment of insulin resistance (HOMA-IR) (version 2.2.3) [19]. We used the median value of 
data collected at time points $\mathrm{t}=-20,-10$ and 0 min to compare assessments in the postabsorptive state. Postprandial protein kinetics were measured by using the time points $t=0-240 \mathrm{~min}$ to calculate the area under the curve between 0 and $4 \mathrm{~h}$. AUC was divided by time to obtain an average. As the uptake of food is not complete after $4 \mathrm{~h}$ [17], the postprandial calculations are approximations. In the postabsorptive state, PHE hydroxylation was similar to the rate of net protein balance. We imputed missing values with the median for one subject who did not complete the test day with the protein $+\mathrm{CHO}$ drink to be able to include this subject in the repeated measurement analysis. For $\mathrm{BMI} \mathrm{FEV}_{1}$ (\% of predicted), postabsorptive $\mathrm{PS}$ and $\mathrm{PB}$, postprandial insulin, glucose, $\mathrm{PS}, \mathrm{PB}$, and net protein balance responses the normality or equal variance test failed, and data were log-transformed. Two-factor repeated measures analysis of variance with "group" and "protein drink" was used to test for effects and interactions between controls and patients and protein drinks. If there was a significant main effect or interaction, we used Tukey's multiple comparisons test to evaluate within group differences. The level of significance was set at $P<0.05$. The statistical package within Graphpad Prism (version 7.0a) was used for data analysis.

\section{Results}

We enrolled in total 29 participants. While one participant completed only three out of four test days, 20 participants completed the entire study (Supplemental Fig. 1). The COPD patients were significantly different from healthy age matched controls for lung function $(\mathrm{P}<0.0001)$ and smoking history $(\mathrm{P}<0.001)$ (Supplemental Table 1). On group level, body weight and composition measures were comparable. Five out of 10 COPD patients, and 4 out of 11 controls were characterized by an impaired fasting glucose concentration $(\geq 5.6 \mathrm{mmol} / \mathrm{L})$.

\subsection{Postprandial plasma amino acid concentration changes}

Between and within groups, the average postprandial increase in plasma PHE concentrations over the $4 \mathrm{~h}$ postprandial period to the four protein drinks were comparable, except for a smaller increase in the response to the protein $+\mathrm{CHO}+$ LEU drink in the COPD group as compared to the other three drinks (Fig. 2A).

The average plasma LEU concentration increases were higher in the COPD group $(P=0.0020)$, and dependent on the protein drink in both groups $(P<0.0001)$ (Fig. $2 \mathrm{~B})$. When comparing the four protein drinks within groups, the average plasma LEU concentration increases for the two LEU supplemented drinks were higher compared to the two drinks without additional free LEU $(P<0.0001)$. Only in COPD patients we observed a lowering effect of $\mathrm{CHO}$ co-ingestion on the LEU concentration increase. Supplemental Fig. 2 shows the plasma PHE and LEU concentration responses over time in both groups.

\subsection{Postprandial plasma glucose and insulin concentration changes}

In the postabsorptive state, we found no differences in plasma glucose and insulin levels or HOMA index for IR between the groups (Supplemental Table 1), although there was a tendency toward a higher HOMA index for IR in COPD patients $(P=0.0516)$. The average postprandial plasma glucose concentration increases in response to the four protein drinks were dependent on the protein drink, but not on the group. When comparing the four protein drinks within groups, the glucose concentration increases between the two $\mathrm{CHO}$ supplemented drinks were comparable, and higher compared to the two protein drinks without $\mathrm{CHO}(P<0.001)$ (Fig. 3A).

The average postprandial plasma insulin concentration increases in response to the four protein drinks were dependent on the protein drink $(P<0.0001)$, but not on the group. When comparing the four protein drinks within groups, the insulin concentration increases were comparable for the two protein drinks to which we added $\mathrm{CHO}$, and higher compared to the two protein drinks without $\mathrm{CHO}(P<0.0001)$ (Fig. 3B). The insulin concentration increases were not significantly different between the protein and protein + LEU drinks. Only in COPD patients, the protein + LEU drink increased the insulin concentration to such an extent that we did not observe a significant difference from the protein + CHO drink. Supplemental Fig. 3 shows the plasma glucose and insulin concentration responses over time in both groups.

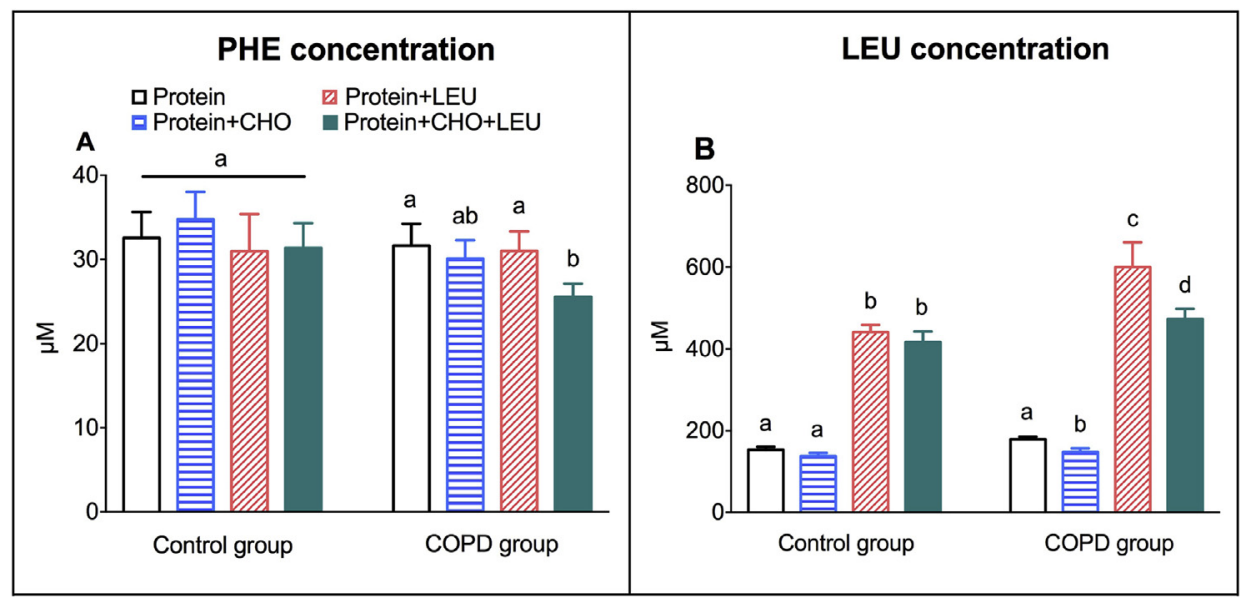

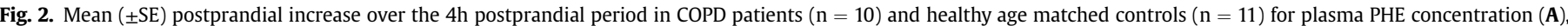

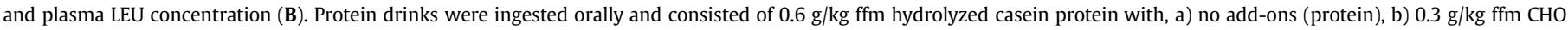

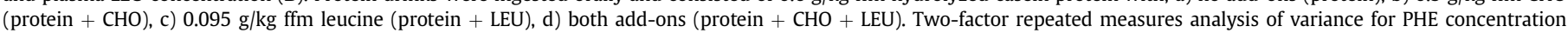

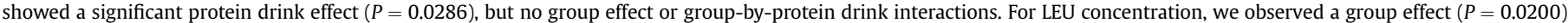

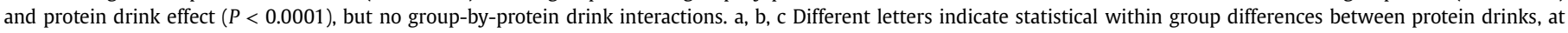
$P<0.05$. CHO: carbohydrates. COPD: chronic obstructive pulmonary disease. ffm: fat-free mass. LEU: leucine. 


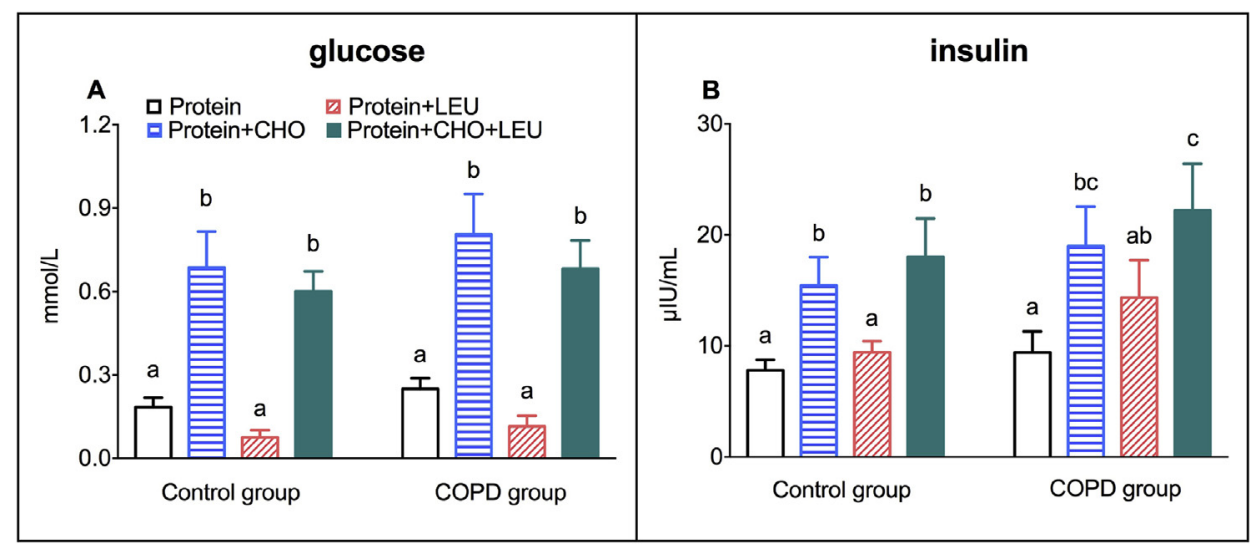

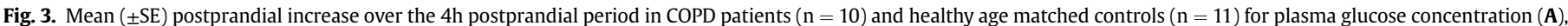

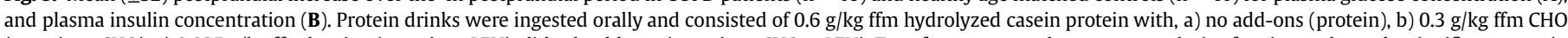

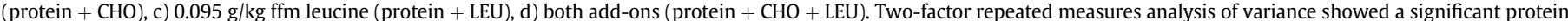

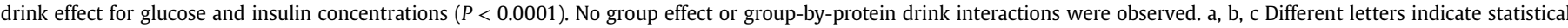

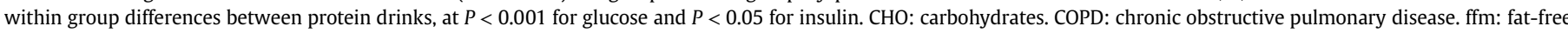
mass. LEU: leucine.

\subsection{Whole body protein turnover responses}

Data regarding plasma isotope enrichments can be found in Fig. 4. In the healthy group, a significant time effect was found for L[ring- ${ }^{2} \mathrm{H}_{5}$ ]-PHE, L- $\left[{ }^{15} \mathrm{~N}\right]-\mathrm{PHE}, \mathrm{L}-\left[\mathrm{U}-{ }^{13} \mathrm{C}_{9},{ }^{15} \mathrm{~N}\right]$-TYR, L-[ring- $\left.{ }^{2} \mathrm{H}_{4}\right]-\mathrm{TYR}$ $(P<0.0001)$ and time-by-protein drink interaction for $\mathrm{L}-\left[\mathrm{ring}_{-}{ }^{2} \mathrm{H}_{5}\right]-$ PHE, L- $\left[{ }^{15} \mathrm{~N}\right]-\mathrm{PHE}, \mathrm{L}-\left[\right.$ ring- $\left.{ }^{2} \mathrm{H}_{4}\right]$-TYR $(P<0.0001)$, L-[U- $\left.{ }^{13} \mathrm{C}_{9},{ }^{15} \mathrm{~N}\right]-$ TYR $(P=0.07)$. In the COPD group, a significant time effect was found for L-[ring- $\left.{ }^{2} \mathrm{H}_{5}\right]-\mathrm{PHE}, \mathrm{L}-\left[{ }^{15} \mathrm{~N}\right]-\mathrm{PHE}, \mathrm{L}-\left[\mathrm{U}-{ }^{13} \mathrm{C}_{9},{ }^{15} \mathrm{~N}\right]-\mathrm{TYR}, \mathrm{L}-$ [ring- ${ }^{2} \mathrm{H}_{4}$ ]-TYR $(P<0.0001)$ and time-by-protein drink interaction for $\mathrm{L}_{-}\left[{ }^{15} \mathrm{~N}\right]-\mathrm{PHE}(P<0.0001)$. No protein drink effects were observed for any of the measures in the COPD and control groups. Postabsorptive whole body PS and PB were comparable between controls and COPD patients (Supplemental Table 2). Also, no significant difference in postabsorptive net protein balance was observed between the groups.

Changes from baseline for PS and PB in response to the four protein drinks were dependent on the group, with greater increases for PS $(P=0.0060)$ and smaller decreases in $\mathrm{PB}(P=0.0448)$ in the COPD group (Fig. 5A, B). For net protein balance we observed no differences between the groups (Fig. 5C). Moreover, SPE was lower in the COPD group $(P=0.0244)$, without any within group differences between the four protein drinks (Supplemental Table 3). In both groups, changes from baseline for PS, PB, and net protein balance were comparable between all four protein drinks.

\section{Discussion}

In the present study, we examined whole body protein metabolism in response to a serving of high-quality protein with or without the addition of free leucine and/or carbohydrates in normal weight older adults with moderate to severe COPD and dyspnea who are at risk for muscle loss, as compared to healthy older adults. Despite differences in plasma LEU and insulin responses, we found in both groups that co-ingestion of free LEU and/or CHO with a serving of high-quality protein did not further enhance PS, reduce $\mathrm{PB}$, or improve net whole body protein anabolism.

\subsection{Leucine and insulin}

Although high-quality proteins [4], and specifically dietary essential amino acids [5] are very effective in the acute stimulation of protein anabolism in COPD patients, the specific contribution of LEU remains unclear as $\mathrm{CHO}$ were always a part of the protein/amino acid meals. Furthermore, this patient group is often characterized by alterations in LEU metabolism $[5,10,11]$ and glucose intolerance $[12,13]$. Previous findings were based on half the amount of the same high-quality protein and a similar amount of $\mathrm{CHO}$ as provided in the present study. The current study confirms and extends previous findings regarding the absence of an anabolic effect of LEU co-ingestion to a high-quality protein in COPD patients and age matched controls [4]. The addition of free LEU (together with isoleucine and valine) to a low-quality soy protein, however, was associated with a stimulation of whole body PS in COPD patients [13], but not in healthy controls. In that study, the addition of free LEU was also associated with a reduction in splanchnic amino acid extraction, which we did not observe in the present study.

Based on previous studies in healthy older adults, reporting increases in mixed muscle protein and myofibrillar muscle FSR after LEU co-ingestion [20-22], we expected to find an increase in whole body PS. Interestingly, the study that reported the highest increase in FSR by LEU co-ingestion did not observe an increase in whole body PS [22], suggesting that increases in muscle FSR could be paired with reductions in PS elsewhere in the body.

LEU and $\mathrm{CHO}$ partially work through the same mechanism to promote increases in protein anabolism, namely by stimulation of insulin, whereas LEU also directly activates anabolic signaling [6,7]. In the present study, we observed in both groups that $\mathrm{CHO}$ coingestion with protein or protein + LEU stimulated the insulin response. Regarding the insulinotropic properties of LEU [6,23], which are at least in part ascribed to various metabolic processes within the pancreatic $\beta$-cell [24], we observed that the leucine dose induces an insulin response just not above that of the protein and/ or CHO load.

The higher plasma insulin concentrations associated with the co-ingestion of $\mathrm{CHO}$ did not result in significant increases in whole body PS or protein anabolism in either group. In line, other studies have also shown that $\mathrm{CHO}$ co-ingestion does not further stimulate protein synthesis [25-29]. These findings are also in line with studies showing that plasma insulin concentrations higher than those obtained via protein or amino acid intake alone do not stimulate muscle FSR [27,28,30]. Insulin however appears to primarily act on protein breakdown [9]. An insulin induced 


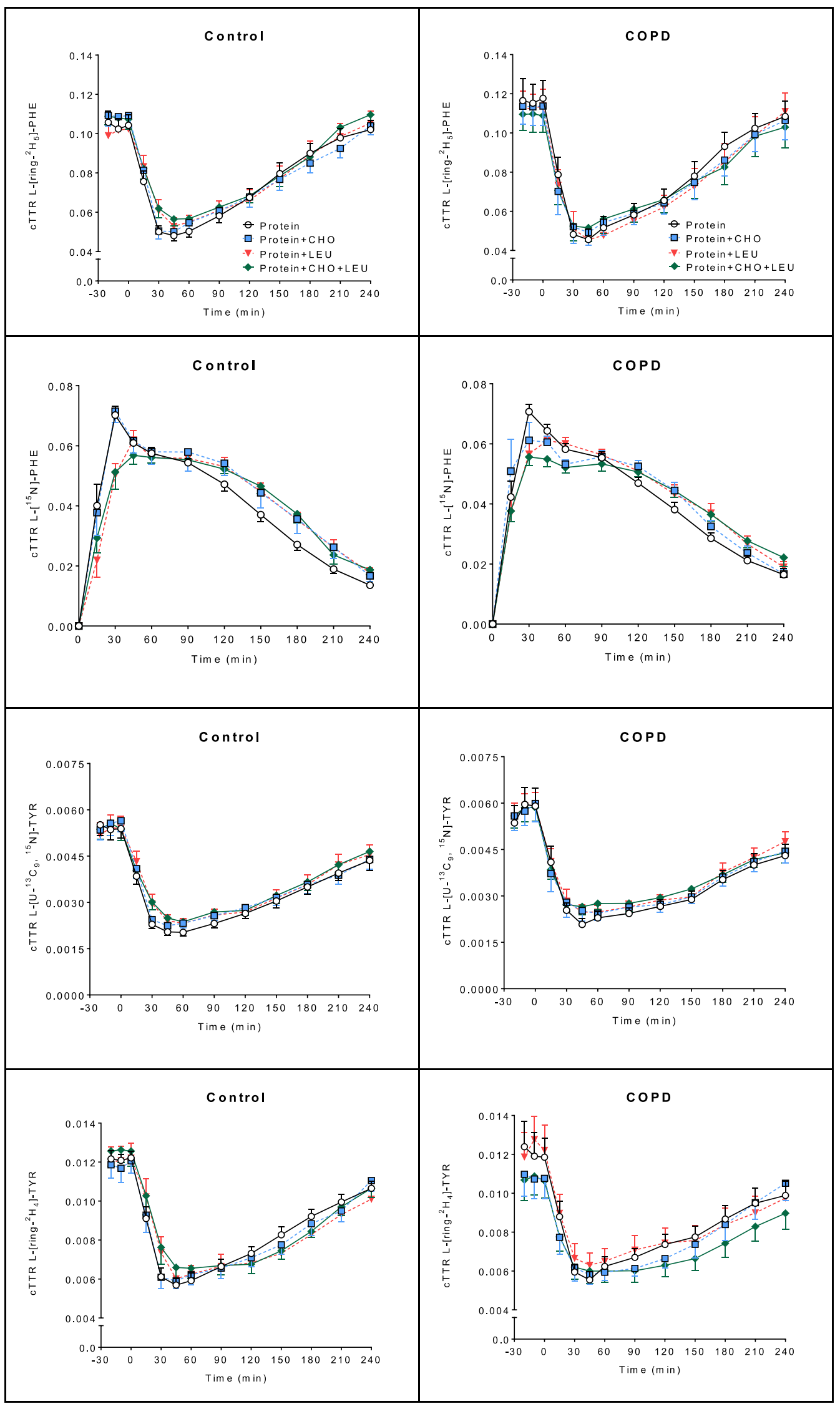

Fig. 4. Mean $\left({ }_{ \pm}\right.$SE) plasma cTTR in healthy controls $(\mathrm{n}=11)$ for $\mathrm{L}-\left[\right.$ ring $\left.-{ }^{2} \mathrm{H}_{5}\right]-\mathrm{PHE}(\mathbf{A 1}), \mathrm{L}-\left[{ }^{15} \mathrm{~N}\right]-\mathrm{PHE}(\mathbf{B 1}), \mathrm{L}-\left[\mathrm{U}-{ }^{13} \mathrm{C}_{9},{ }^{15} \mathrm{~N}\right]-\mathrm{TYR}(\mathbf{C 1})$, and L-[ring- $\left.{ }^{2} \mathrm{H}_{4}\right]-\mathrm{TYR}(\mathbf{D 1})$, before and after intake of 4 different protein drinks. Protein drinks were ingested orally (at time $=0 \mathrm{~min}$ ) and consisted of $0.6 \mathrm{~g} / \mathrm{kg} \mathrm{ffm}$ hydrolyzed casein protein with, a) no add-ons (protein), b) $0.3 \mathrm{~g} / \mathrm{kg}$ 


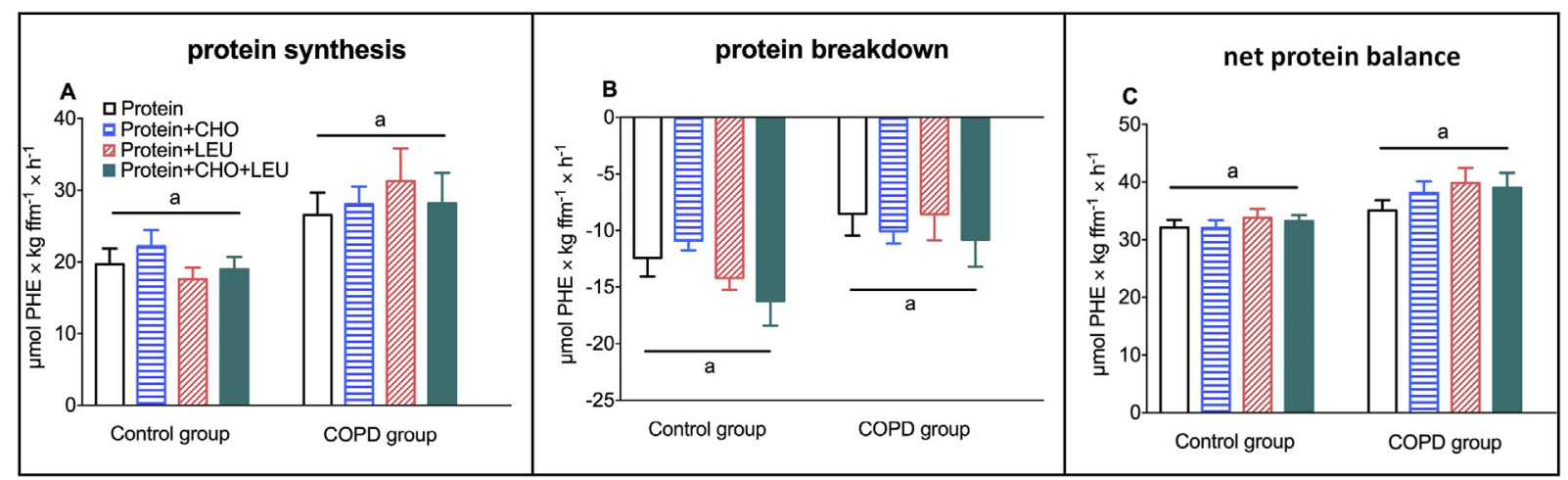

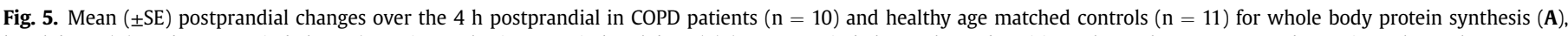

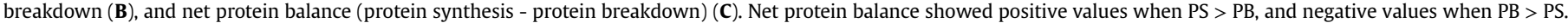

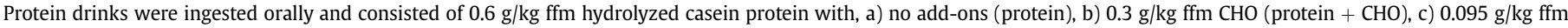

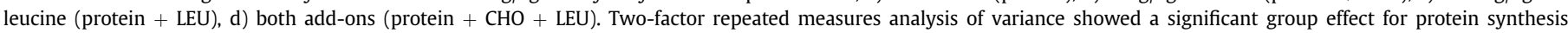

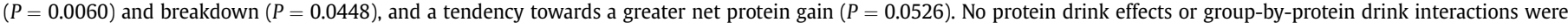
observed for any of the measures. CHO: carbohydrates. COPD: chronic obstructive pulmonary disease. ffm: fat-free mass. LEU: leucine.

reduction in muscle PB was previously observed in young adults for plasma insulin concentrations up to $30 \mu \mathrm{IU} \times \mathrm{mL}^{-1}$ [9]. As the protein only intake already resulted in peak insulin concentrations of $20-25 \mu \mathrm{IU} \times \mathrm{mL}^{-1}$ (Supplemental Fig. 5), it is possible that a maximum reduction in whole body $\mathrm{PB}$ was already established.

\subsection{Healthy versus COPD}

Nutritional approaches that provide an optimal stimulation of muscle protein anabolism are of clinical importance even in normal weight COPD patients with a poor appetite or severe dyspnea. These patients are at risk for muscle loss as disturbances in intermediary amino acid and protein metabolism are present independent of their nutritional status [1-3]. Furthermore, minimizing supplement dose by optimizing the quality is clinically important particularly in dyspneic COPD patients as feeding induced dyspnea may impair their food intake. In this study, lung function in the COPD group was severely impaired, all had moderate to severe dyspnea, 7 out of the 10 patients were dependent on supplemental oxygen, and 5 of them had elevated fasting glucose concentrations $\geq 5.6 \mathrm{mmol} / \mathrm{L}$. For those reasons, we were surprised not to find a lower FFM and appendicular skeletal muscle index on whole group level in the COPD patients compared to the controls. Appendicular skeletal muscle index was below the cut-off for sarcopenia $\left(<7.23 \mathrm{~kg} \times \mathrm{m}^{-2}\right.$ for men; $<5.67 \mathrm{~kg} \times \mathrm{m}^{-2}$ for women) [31] in 6 of the studied COPD patients versus only in one control subject.

Previously we have established that the use of the oral tracer of $15 \mathrm{~N}$-Phe and unlabeled tracee (dietary PHE) display the same digestion and absorption characteristics for protein mixtures consisting of hydrolyzed proteins [4]. In COPD patients, we found a tendency towards a greater stimulation of whole body protein anabolism, due to higher values for PS and lower values for PB, suggesting a disease related effect on postprandial protein turnover. The splanchnic area likely plays an important role, as a lower extraction of amino acids by the portal drained viscera, as observed in this study and likewise in our other studies in COPD $[1,3-5]$ is related to higher peripheral essential amino acid availability (i.e. appearance), and subsequently greater protein anabolism [5].

It remains unclear whether the group differences in PHE vs. LEU concentration responses indicates compromised LEU oxidation, as previously disturbances in LEU metabolism and a discrepancy among the individual BCAAs have been observed in COPD $[5,10,11]$, and/or greater PHE to TYR conversion in these patients. Accurate measurement of LEU oxidation might be difficult in COPD due to air trapping and $\mathrm{CO}_{2}$ retention in the lungs. The reduced splanchnic extraction (SPE) has been a consistent finding in many of our previous studies resulting in a greater net protein balance. The reduced SPE we previously observed was present for PHE but also for many amino acids including LEU [1]. In that study despite lower SPE in COPD, no differences were found in plasma amino acid levels during whey sip feeding between the groups. A feeding reducing effect was not present for endogenous rate of appearance (reflecting protein breakdown) in COPD for LEU like it was present for PHE. Moreover, plasma levels were not elevated in the prandial state for both amino acids suggesting immediate oxidation of LEU or incorporation into protein.

In conclusion, we did not observe any individual or combined anabolic effects on whole body protein metabolism of CHO and LEU when co-ingested with a serving of high-quality protein in patients with moderate to severe COPD and dyspnea or healthy older adults. Whether this is also the case for COPD patients characterized by with recent involuntary weight loss or muscle wasting is of interest for future studies.

\section{Author contributions}

RJ, ND and ME had full access to all of the data in the study and take responsibility for the integrity of the data and the accuracy of the data analysis. RJ, ND, and ME designed and conducted the

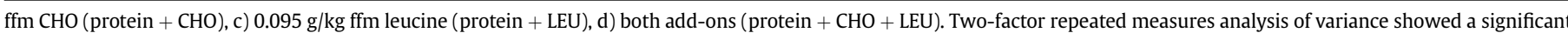

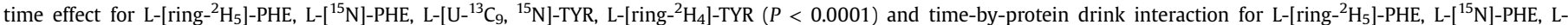

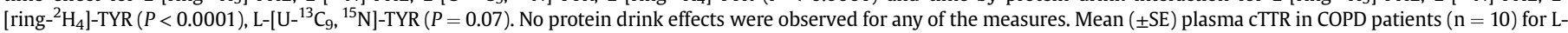

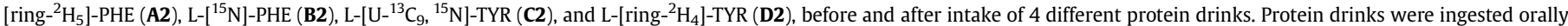

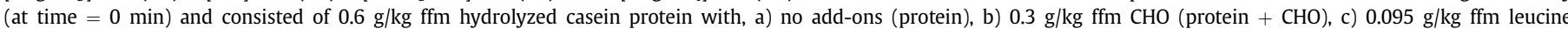

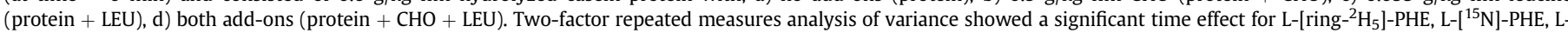

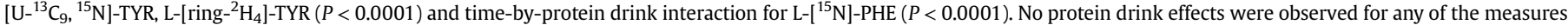

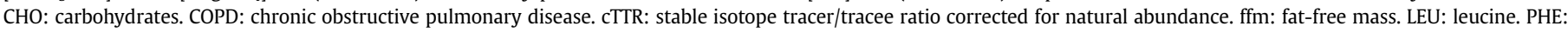
phenylalanine. TYR: tyrosine. 
research. RJ, ND, and ME were involved in the data analysis and writing of the manuscript. AS reviewed the manuscript. EV, RH, and $\mathrm{AZ}$ were involved in the recruitment of study participants.

\section{Conflicts of interest}

The authors have no conflict of interest to declare.

\section{Acknowledgments}

We sincerely thank the COPD patients and the healthy control subjects who have participated in this research and made this work possible. Furthermore, the authors thank chief analytical chemist John Thaden, PhD, for sample analysis. Funder of the research is the National Institutes of Health (Grant IDs: P30-ES023512-01; HL095903; S10-RR027047).

\section{Appendix A. Supplementary data}

Supplementary data related to this article can be found at https://doi.org/10.1016/j.clnu.2018.08.006.

\section{References}

[1] Engelen MP, De Castro CL, Rutten EP, Wouters EF, Schols AM, Deutz NE. Enhanced anabolic response to milk protein sip feeding in elderly subjects with COPD is associated with a reduced splanchnic extraction of multiple amino acids. Clin Nutr (Edinburgh, Scotland) 2012;31(5):616-24.

[2] Engelen MP, Deutz NE, Mostert R, Wouters EF, Schols AM. Response of wholebody protein and urea turnover to exercise differs between patients with chronic obstructive pulmonary disease with and without emphysema. Am Clin Nutr 2003;77(4):868-74.

[3] Engelen MP, Rutten EP, De Castro CL, Wouters EF, Schols AM, Deutz NF. Altered interorgan response to feeding in patients with chronic obstructive pulmonary disease. Am J Clin Nutr 2005;82(2):366-72.

[4] Jonker R, Deutz NE, Erbland ML, Anderson PJ, Engelen MP. Hydrolyzed casein and whey protein meals comparably stimulate net whole-body protein synthesis in COPD patients with nutritional depletion without an additional effect of leucine co-ingestion. Clin Nutr (Edinburgh, Scotland) 2014:33(2):211-20.

[5] Jonker R, Deutz NE, Erbland ML, Anderson PJ, Engelen MP. Effectiveness of essential amino acid supplementation in stimulating whole body net protein anabolism is comparable between COPD patients and healthy older adults. Metab Clin Exp 2017:69:120-9.

[6] Anthony JC, Lang CH, Crozier SJ, Anthony TG, MacLean DA, Kimball SR, et al. Contribution of insulin to the translational control of protein synthesis in skeletal muscle by leucine. Am J Physiol 2002;282(5):E1092-101.

[7] Anthony JC, Reiter AK, Anthony TG, Crozier SJ, Lang CH, MacLean DA, et al. Orally administered leucine enhances protein synthesis in skeletal muscle of diabetic rats in the absence of increases in 4E-BP1 or S6K1 phosphorylation. Diabetes 2002:51(4):928-36.

[8] Timmerman KL, Lee JL, Dreyer HC, Dhanani S, Glynn EL, Fry CS, et al. Insulin stimulates human skeletal muscle protein synthesis via an indirect mechanism involving endothelial-dependent vasodilation and mammalian target of rapamycin complex 1 signaling. J Clin Endocrinol Metabol 2010;95(8):3848-57.

[9] Greenhaff PL, Karagounis LG, Peirce N, Simpson EJ, Hazell M, Layfield R, et al. Disassociation between the effects of amino acids and insulin on signaling ubiquitin ligases, and protein turnover in human muscle. Am J Physiol 2008;295(3):E595-604.

[10] Engelen MP, Schols AM. Altered amino acid metabolism in chronic obstructive pulmonary disease: new therapeutic perspective? Curr Opin Clin Nutr Metab Care 2003:6(1):73-8.

[11] Engelen MP, Wouters EF, Deutz NE, Menheere PP, Schols AM. Factors contributing to alterations in skeletal muscle and plasma amino acid profiles in patients with chronic obstructive pulmonary disease. Am J Clin Nutr 2000;72(6):1480-7.

[12] Bolton CE, Evans M, Ionescu AA, Edwards SM, Morris RH, Dunseath G, et al. Insulin resistance and inflammation - a further systemic complication of COPD. COPD 2007;4(2):121-6.

[13] Engelen MP, Rutten EP, De Castro CL, Wouters EF, Schols AM, Deutz NE. Supplementation of soy protein with branched-chain amino acids alters protein metabolism in healthy elderly and even more in patients with chronic obstructive pulmonary disease. Am J Clin Nutr 2007;85(2):431-9.

[14] Global strategy for the diagnosis, management and prevention of COPD, global initiative for chronic obstructive lung disease (GOLD). 2016. Available from: http://www.goldcopd.org/.2016.

[15] Hankinson JL, Odencrantz JR, Fedan KB. Spirometric reference values from a sample of the general U.S. population. Am J Respir Crit Care Med 1999;159(1): $179-87$.

[16] Abumrad NN, Rabin D, Diamond MP, Lacy WW. Use of a heated superficial hand vein as an alternative site for the measurement of amino acid concentrations and for the study of glucose and alanine kinetics in man. Metabol Clin Exp 1981;30(9):936-40.

[17] Jonker R, Deutz NEP, Harrykissoon R, Zachria AJ, Veley EA, Engelen M. A critical evaluation of the anabolic response after bolus or continuous feeding in COPD and healthy older adults. Clin Sci (Lond) 2018;132(1):17-31.

[18] Engelen MP, Rutten EP, De Castro CL, Wouters EF, Schols AM, Deutz NE. Casein protein results in higher prandial and exercise induced whole body protein anabolism than whey protein in chronic obstructive pulmonary disease. Metabol Clin Exp 2012;61(9):1289-300.

[19] Levy JC, Matthews DR, Hermans MP. Correct homeostasis model assessment (HOMA) evaluation uses the computer program. Diabetes Care 1998;21(12): 2191-2.

[20] Wall BT, Hamer HM, de Lange A, Kiskini A, Groen BB, Senden JM, et al. Leucine co-ingestion improves post-prandial muscle protein accretion in elderly men. Clin Nutr (Edinburgh, Scotland) 2013;32(3):412-9.

[21] Katsanos CS, Kobayashi H, Sheffield-Moore M, Aarsland A, Wolfe RR. A high proportion of leucine is required for optimal stimulation of the rate of muscle protein synthesis by essential amino acids in the elderly. Am J Physiol 2006;291(2):E381-7.

[22] Rieu I, Balage M, Sornet C, Giraudet C, Pujos E, Grizard J, et al. Leucine supplementation improves muscle protein synthesis in elderly men independently of hyperaminoacidaemia. J Physiol 2006;575(Pt 1):305-15.

[23] Newsholme P, Brennan L, Rubi B, Maechler P. New insights into amino acid metabolism, beta-cell function and diabetes. Clin Sci (Lond). 2005;108(3): 185-94.

[24] van Loon LJ. Leucine as a pharmaconutrient in health and disease. Curr Opin Clin Nutr Metab Care 2012;15(1):71-7.

[25] Koopman R, Beelen M, Stellingwerff T, Pennings B, Saris WH, Kies AK, et al. Coingestion of carbohydrate with protein does not further augment postexercise muscle protein synthesis. Am J Physiol 2007;293(3):E833-42.

[26] Staples AW, Burd NA, West DW, Currie KD, Atherton PJ, Moore DR, et al. Carbohydrate does not augment exercise-induced protein accretion versus protein alone. Med Sci Sports Exerc 2011;43(7):1154-61.

[27] Glynn EL, Fry CS, Timmerman KL, Drummond MJ, Volpi E, Rasmussen BB. Addition of carbohydrate or alanine to an essential amino acid mixture does not enhance human skeletal muscle protein anabolism. J Nutr 2013;143(3): 307-14.

[28] Hamer HM, Wall BT, Kiskini A, de Lange A, Groen BB, Bakker JA, et al. Carbohydrate co-ingestion with protein does not further augment post-prandial muscle protein accretion in older men. Nutr Metabol 2013;10(1):15.

[29] Gorissen SHM, Burd NA, Hamer HM, Gijsen AP, Groen BB, van Loon LJC. Carbohydrate co-ingestion delays dietary protein digestion and absorption but does not modulate postprandial muscle protein accretion. J Clin Endocrinol Metabol 2014;99(6):2250-8.

[30] Groen BB, Horstman AM, Hamer HM, de Haan M, van Kranenburg J, Bierau J, et al. Increasing insulin availability does not augment postprandial muscle protein synthesis rates in healthy young and older men. J Clin Endocrinol Metabol 2016;101(11):3978-88.

[31] Cruz-Jentoft AJ, Baeyens JP, Bauer JM, Boirie Y, Cederholm T, Landi F, et al. Sarcopenia: European consensus on definition and diagnosis: report of the European working group on sarcopenia in older people. Age Ageing 2010;39(4):412-23. 